ISSN(print): 2644-0490, ISSN(online): 2644-0504

Volume 4 Issue 03 March 2021

Article DOI: 10.47191/jefms/v4-i3-01, Impact Factor: 6.228

Page No.- 99-105

\title{
The Influence of Leadership Style and Motivation on Employee Performance in the Department of Transportation, Tourism, Communication and Informatics in Ngada District
}

\author{
Maria Oktavianus Botha Djawa
}

ABSTRACT: Organizational goals stated in the vision and mission of the organization are influenced by employee performance and leadership style. The Department of Transportation, Tourism, Communication and Information Technology is a government organization that provides services to the community in the fields of transportation, tourism, and communication and information technology. The purpose of this study was to (1) analyze the effect of leadership style on employee performance. (2) The effect of employee motivation on employee performance. This research is a case study at the Department of Transportation, Tourism, Communication and Information, Ngada Regency. The method used is descriptive quantitative research.

The results showed that: (1) there is a positive and significant influence of leadership style on employee performance. (2) There is an influence of motivation on employee performance in the Department of Transportation, Tourism, Communication and Informatics, Ngada Regency. This research can be used to become a reference for the leadership of the Ngada Regency Department of Transportation, Tourism, Communication and Information in carrying out their duties to control the organization in achieving organizational goals effectively through leadership styles to improve employee performance.

\section{PRELIMINARY}

Tourism development in Ngada Regency is inseparable from the efforts made by the government, the business community and the community in order to preserve nature and culture as a valuable and irreplaceable heritage. Tourism development also aims at, among others; promote economic growth, improve people's welfare, unemployment, preserving nature, the environment and resources of others, strengthen the identity and unity of the nation, also important is to strengthen the press a habatan between nations, so that the development of tourism is also intended to improve the image of the tourism it self. To achieve the goal of the performance of employees at the Department of Transportation, Tourism, Communication and Information must be improved. Therefore, the role of the leader is expected to be able to apply the right leadership style and act as a figure that moves his subordinates, rational, full of initiative and intelligence in decision making, the ability to solve problems which in turn can improve employee performance.

The success of achieving these goals also depends on the individuals in the organization as employees to achieve one goal. The Department of Transportation, Tourism, Communication and Information of Ngada Regency is a public organization that exists to provide services to the community in the sector of transportation, tourism, communication and informatics. As an organization to carry out basic tasks, functions and authority to achieve the desired objectives is strongly influenced by the performance of the employee and the organization's overall performance. The performance of employees is the result of one's work achieved in a period of time in doing one's main duty, functions, authority and responsibility appropriate position within the organizational structure. Organizational performance is the synergy of the performance of all employees in an organization in a period of time.

This Research is a case study in the Department of Transportation, Tourism, Communications and Information Ngada Regency, with respondents are all employees of 64 . The aim of this study to analyze (1). The effect of leadership style on employee performance. (2) The influence of motivation on employee performance. The research method used is descriptive quantitative research methods. The research was restricted to the dependent variable is the performance of the employee, while the independent variable is the style of leadership and motivation. 


\section{The Influence of Leadership Style and Motivation on Employee Performance in the Department Of Transportation, Tourism, Communication and Informatics in Ngada District}

\section{DISCUSSION}

\section{Performance}

Performance is work performance, namely the comparison between work results and the standards set by Dessler, (2000). Performance is the result of work both in quality and quantity achieved by a person in carrying out tasks according to given responsibilities (Mangkunagara, 2002: 22).

Performance is the result or level of success of a person as a whole during a certain period in carrying out a task compared to various possibilities, such as work standards, targets or targets or criteria that have been determined in advance that have been mutually agreed (Rivai and Basri, 2005: 50) Minner (in Sutrisno, 2011) suggests four aspects used to assess performance, namely:

1) The quality produced, explains the number of errors, time and accuracy in carrying out tasks;

2) The quantity produced, with respect to some amount of the product or service produced;

3) Working time, explaining the number of absences, tardiness, and years of work that the individual employee has experienced;

4) Cooperation, explaining how individuals help or hinder the efforts of their colleagues

Performance is a work result that can be achieved by a person or group of people in an organization in accordance with their respective duties, functions, authorities and responsibilities in order to achieve the goals of the organization concerned legally, does not violate the law and is in accordance with norms or ethics, according to Prawirosentono's opinion. in Husaini Usman (2010).

Based on the various views on performance mentioned above, it can be concluded that employee performance is the work achieved by a person or group of people in an organization, according to their main duties, functions, authorities and responsibilities according to their position in the organizational structure in order to legally achieve organizational goals, in accordance with morals and ethics. Performance has an important meaning in an organization or company to support the achievement of organizational goals

\section{Leadership}

According to Tjiptono (2006: 161) leadership style is a way that leaders interact with their subordinates. Meanwhile, another opinion states that leadership style is a pattern of behavior (words and actions) of a leader that is felt by others (Hersey, 2004: 29).

Robert House's Path Goal theory seeks to explain the influence of leader's behavior on motivation, satisfaction, and job execution of his subordinates (Miftah Thoha, 2007: 42). Path Goal Theory distinguishes four styles k epemimpinan is as follows:

a. Leadership Directive

This type is equally expected in an autocratic leadership model; subordinates know exactly what is expected of them and special direction is given by the leader. In this model there is no participation from his subordinates.

b. Supportive Leadership

This leadership has a willingness to explain itself, tries, is easy to approach, and has genuine human concern for its subordinates.

\section{c. Participatory Leadership}

In this leadership style, leaders try to ask for and use suggestions from their subordinates. But the decision still air a da him.

d. Leadership Oriented to Performance

This leadership style sets a series of goals that challenge subordinates to expectations. Leaders also give confidence to them that they are able to perform job duties achieve goals well (Miftah Thoha, 20 12: 42).

Based on these various views, it is clear that leadership is one of the central factors in the management of an organization both for profit-motivated organizations, community organizations and government organizations. An organization that is successful in achieving its goals and is able to fulfill its social responsibilities will depend heavily on its leaders. If the leader is able to carry out the main duties and functions effectively, it will enable the organization to achieve its goals. Therefore, every organization requires the presence of an effective leader who has the ability to influence the behavior of its members.

\section{Motivation}

According to Maslow in Reksohadiprojo and Handoko (1996), human needs can be distinguished as follows:

\section{a. Physiological Needs}

Physiological needs are the most basic hierarchy of human needs which are the needs to be able to live such as eating, drinking, housing, oxygen, sleep and so on. 


\section{The Influence of Leadership Style and Motivation on Employee Performance in the Department Of Transportation,}

Tourism, Communication and Informatics in Ngada District

\section{b). Security Needs}

When the relative physiological needs are satisfied, then a second need arises, namely the need for security. The need for a sense of security includes security for protection from the dangers of work accidents, guarantees of continuity of work and guarantees of old age when they are no longer working.

\section{c). Social Needs}

If the physiological needs and security are minimally satisfied, then social needs will emerge, namely the need for friendship, affiliation and closer interaction with others. In the organization of this case relates to the need to be the working group is compact, good supervision, rekreation together and so on.

\section{d). Need for Awards}

This need includes the need to be respected, valued for one's achievements, recognition of one's abilities and expertise and the effectiveness of one's work.

e) Need for Actualization D iri

Self-actualization is Maslow's highest hierarchy of needs. Self-actualization refers to the process of developing one's true potential. The need to demonstrate one's abilities, skills and potential. In fact, the need for self-actualization has a tendency to increase its potential because people actualize their behavior. A person who is dominated by the need for self-actualization likes tasks that challenge his abilities and expertise.

Maslow's theory assumes that people in power fulfill more basic (physiological) needs before directing behavior to fulfill higher needs (self-realization). Lower needs must be met first before higher needs such as self-manifestation begin to restore one's behavior. The important thing in Maslow's thinking is that the needs that have been met provide motivation. When a person decides that he receives sufficient money for the work of the organization where he works, money has no more intense power. So when a need reaches its peak, that need will stop being the main motivation for behavior. Then the second need dominates, but even though the need has been satisfied, the need still affects behavior only with a smaller intensity.

\section{RESEARCH METHODS}

This research design uses quantitative research methods in order to determine whether there is an influence of Organizational Culture and Leadership Style on Employee Performance of the Office of Transportation, Tourism, Communication and Informatics of Ngada Regency. The population of this study were all 64 employees at the Department of Transportation, Tourism, Communication and Informatics of Ngada Regency. The research instrument used is a questionnaire and data collection techniques in this study using a survey method with a closed questionnaire.

The research method used is descriptive analysis and influence analysis. Descriptive analysis is used to provide an empirical description or description of the data collected in the study by knowing the respondents 'general perceptions regarding the degree of respondents' perceptions. While the influence analysis consists of classical assumption test, multiple linear regression analysis, and hypothesis testing.

\section{RESULTS AND DISCUSSION}

In this study, hypothesis testing was carried out on the variable leadership style (X1), motivation (X2) and employee performance (Y) which was done partially.

\section{a. Partial Test ( $t$ test)}

The $t$ test is used to show how far the influence of each independent variable individually / partially in explaining the variation in the dependent variable. In the $t$ test, the calculated $t$ value will be compared with the $t$ table value or can also compare the $\operatorname{sig}$ (probability) with the critical point of $5 \%$. The results of the $t$ test calculations are presented in the following table. This test is used to determine the partially significant effect of the independent variable on the dependent variable. The test criterion is that $\mathrm{H}_{0}$ is accepted if $\mathrm{t}$ count $<$, or prob-sig $>\alpha$, where $\alpha=0.05$; and vice versa $\mathrm{H}_{0}$ is rejected if $\mathrm{t}$ count $>$, or prob-sig $<\alpha$, where $\alpha=$ 0.05

Table-4.12 Partial Test results

\begin{tabular}{lllll}
\hline Variabel & Regression Coefficient & Coefficient standarised & $\boldsymbol{t}$ & P-Value \\
\hline (1) & $\mathbf{( 2 )}$ & $\mathbf{( 3 )}$ & $\mathbf{( 4 )}$ & $\mathbf{( 5 )}$ \\
(Constants ) & 0,37 & - & 0,066 & 0,948
\end{tabular}


The Influence of Leadership Style and Motivation on Employee Performance in the Department Of Transportation, Tourism, Communication and Informatics in Ngada District

\begin{tabular}{lllll} 
Leadership Style (X1) * & 0,54 & 0,60 & 4,812 & 0,000 \\
\hline Motivation (X2)* & 0,45 & 0,29 & 2,336 & 0,023 \\
\hline
\end{tabular}

* Significantly affects employee performance at a significance level $(\alpha)=5 \%$

Decision: $\mathrm{V}$ ariabel significant if $\mathrm{P}$-value $<0,05$

1) Testing the leadership style variable regression coefficient (X1)

Based on the results of the $t$ test as seen in the table above, it shows that the value of $t$ count $(4,812)>t$ table $(1.99897)$. While the significance value obtained is 0.000 smaller $(<)$ than the value $\alpha=0.05$. Therefore the decision was $\mathrm{H}_{0}$ is rejected and $\mathrm{H}_{\mathrm{a}}$ accepted meaning partially leadership style variable (X1) and a significant positive effect on employee performance (Y).

2) Testing the regression coefficient of the motivation variable (X2)

In testing for this motivation variable, the attachments for the printout of the SPSS results, it was found that the $t$ value $(2,336)$ was greater $(>)$ than $t$ table (1.998). While the significance value obtained (0.023) is greater $(>)$ than the value $\alpha=0.05$, then the decision is that $\mathrm{H}_{0}$ is rejected and $\mathrm{H}_{\mathrm{a}}$ is accepted, where partially the Motivation variable (X2) has a significant effect on employee performance $(\mathrm{Y})$.

Conclusion: With a significance level of $5 \%$ it can be said that the variables of leadership style and motivation partially affect the performance of the employees of the Department of Transportation, Tourism, Communication and Information, Ngada Regency.

\section{b. Simultaneous Test (Test F)}

The $\mathrm{F}$ test shows whether the independent variables included in the model have a simultaneous influence on the value of the dependent variable. The following is the result of the $\mathrm{F}$ test calculation which is presented in the table below.

Table -4.13

ANOVA $^{\mathrm{a}}$

\begin{tabular}{|ll|l|l|l|l|l|}
\hline Model & & Sum of Squares & Df & Mean Square & F & Sig. \\
\hline \multirow{2}{*}{1} & Regression & 3774,253 & 2 & 1887,126 & 86,790 &, $000^{\mathrm{b}}$ \\
& Residual & 1326,356 & 61 & 21,744 & & \\
& Total & 5100,609 & 63 & & & \\
\hline
\end{tabular}

a. Dependent Variable: Employee Performance

b. Predictors: (Constant), Motivation, Leadership Style

Based on the table above shows calculated $F$ value of 86.790 with a significance probability of 0.000 . This means that the probability value $<0.05$, so it can be concluded that the variable leadership style and motivation simultaneously (together) affect the performance of the employees of the Office of Transportation, Tourism, Communication and Information Technology in Ngada Regency.

\section{c. Coefficient of Determination}

The coefficient of determination is used to determine how much the ability of the independent variable in explaining the dependent variable. The value of determination is determined by the value of $R$ Square. Following are the results of the tests that have been carried out can be seen in the following table

Tabel 4.1

R Square

\begin{tabular}{|l|l|l|l|}
\hline Model & R & R Square & Adjusted R Square \\
\hline 1 &, $860^{\mathrm{a}}$ &, 740 &, 731 \\
\hline
\end{tabular}

a. Predictors: (Constant), Motivation, Leadership Style

b. Dependent Variable: Kary performance a wan

Based on the table above, it is known that the $R$ Square value is 0.740 . This shows that the leadership style and motivation variables can explain 74 percent of the changes in the performance of the employees of the Ngada Regency Office of 


\section{The Influence of Leadership Style and Motivation on Employee Performance in the Department Of Transportation, Tourism, Communication and Informatics in Ngada District}

Tourism, Communication and Information Technology. Meanwhile, the rest is explained or influenced by variables not included in this research model.

Then the hypothesis built by the author is juxtaposed with the results of this study which can be shown in the following discussion:

\section{The Partial Effect of Leadership Style on Employee Performance}

The factors that characterize the leadership style in this study refer to the viewpoint of Robert J. House (in Miftah Toha, 20 12:42) as a dimension to explain leadership styles that affect employee performance, namely: (1) directive leadership; (2) supportive leadership; (3) participatory leadership; (4) there is achievement-oriented leadership.

Based on the results of descriptive analysis of the leadership style variable, it was found that the variable score was 4.039 or it met the criteria quite well, which means that the respondents' assessment of the leadership style in supporting employee performance was quite good. Looking at each leadership style indicator, the average index value is in the range of scores of 166.521 7.7. This shows that employees assess the leadership style indicators to support the achievement of good enough performance.

The results of research and hypothesis testing indicate that leadership style has an effect on employee performance at the Transportation, Turism, Communication and Information office; obtained t value from 20 indicators spread 4, 039 while $t$ table obtained value 1.998, the results showed that $t$ count $>t$ table, so it can be concluded that leadership style affects employee performance.

The results of this study illustrate that the leadership style desired by the employees at the P2KI Office of Ngada Regency is one that is able to direct and motivate employees to work to achieve organizational goals as defined and to evaluate work and tasks that have been carried out by staff in a certain period.

The leader's ability to mobilize employees of the Transportation Tourism, Communication and Information Office Ngada Regency to improve their performance is in the aspect of the ability to lead and motivate employees and the ability to evaluate employee work results. The accuracy of the leadership style according to the wishes of all employees can directly affect their performance (Syafii, 2015, p.1143), so that employees will be moved to work better As stated by Wibowo (2014) that to develop human resources, leaders need to understand workers, develop plans and formulate tactics in developing workers in order to achieve the maximum goals of an organization. Leadership style is a typical way for a leader to think and work in moving the organization by empowering employees to achieve goals, in line with the findings of Eoh's research (2007) that Leadership Style is a typical way of leaders (thinking and acting) to lead the organization consistently to achieve certain goals.

Leadership style in this study refers to the views put forward by Robert J. House ( in Miftah Toha , 2012: 42 ) as a dimension to explain leadership styles that affect employee performance, namely as follows: (1) directive leadership; (2) supportive leadership; (3) participatory leadership; (4) there is achievement-oriented leadership. These findings support the results of previous research by Karolina Koriwati Sangkala (2012) which states that leadership style has a significant influence on employee performance. In addition, this study confirms the results of En Bolle's (2015) study which found that leadership style has a significant influence on employee performance.

The results of this study at the same time support previous research These findings support the results of previous research by Bryan Yohanes Tampi in 2014.The results of his research show that leadership style, motivation has a positive effect on performance, and also Karolina Koriwati Sangkala (2012) who says that leadership style has a significant influence on performance. Employees. In addition, this study confirms the results of En Bolle's (2015) study which found that leadership style has a significant influence on employee performance.

This study also supports the research results of En Bolle (2015), Basri, (2015), Sari (2016) that the use of a good leadership style will have an effect on improving employee performance; Proper leadership is able to create a solid and effective work team in improving employee performance individually and in groups (Boateng, 2013). Besides that, the findings of this study also reject Gusti's (2012) research which states that leadership style has no effect on performance.

From the results of this study, it can be concluded that there is a significant influence between leadership styles on employee performance at the Ngada Regency Department of Transportation, Tourism, Communication and Information.

\section{The Partial Influence of Motivation on Employee Performance}

In this study, the reference is the motivation theory put forward by Maslow (in Reksohadiprojo and Handoko, 1996) which categorizes human needs as motivation for someone to fulfill life's needs. According to Maslow, humans have a level of needs consisting of (1) physical needs, (2) security needs, (3) social needs (4) appreciation needs, (5) self-actualization needs. 
The Influence of Leadership Style and Motivation on Employee Performance in the Department Of Transportation, Tourism, Communication and Informatics in Ngada District

Based on the results of descriptive analysis of the motivation variable, the variable score is 3.303 or it meets good criteria, which means that the respondent's assessment of employee motivation in realizing superior employee performance. Looking at each motivation indicator, the mean index value is in the range of scores 166.5 - 217.7. This shows that employees assess the motivation indicators to support the achievement of good employee performance.

The results of research and hypothesis testing show that motivation has an effect on the performance of the employees of the Transportation, Tourism, Communication and Informatic Office of Ngada Regency. The results obtained by the value of $t$ count 15 indicators equal to the test for this motivation variable it was found that the $t$ value (2.336) was greater $(>)$ than the $t$ table $(1$, 99897 ). While the significance value obtained (0.023) is greater (>) than the value $\alpha=0.05$, then the decision is that H0 is rejected and $\mathrm{Ha}$ is accepted, which means that partially the motivation variable $(\mathrm{X} 2)$ has a significant effect on employee performance $(\mathrm{Y})$.

\section{CLOSING}

\section{Conclusion}

1. Leadership Styles in partially has a significant effect on performace employees of the Department of Transportation, Tourism, Communications and Informatic Ngada Regency

2. Work motivation partially has a significant effect on the performance of the employees of the Department Transportation, Tourism, Communication and Informatic of Ngada Regency

\section{Suggestion}

1. With the findings that the style of leadership is a partial influence on Performance employees at the Department of Transport, Tourism, Communications and Informatic Ngada Regency, then the head of the organization need to improve the quality of leadership style by applying a leadership style that is effective to use the authority positively in moving , pushing and motivating employees in order to improve their performance so that they can support the achievement of the goals set by the organization in a sustainable manner.

2. See the research findings Work Motivation partially influential to the performance of employees at the Department of Transport, Tourism, Communications and Informatic of Ngada regency, then leaders need to create and develop a conducive working atmosphere within the organization, encourages employees to actualize in working and using the means and adequate work facilities so that all employees can move all the capabilities they have to achieve organizational goals efficiently and effectively .

\section{BIBLIOGRAPHY}

1) Aritonang, Lerbin Roberto. 2014. Business Research Methods. The fourth print. Open University Publisher. Banten

2) Basri , Journals Master Manajem en Graduate University of Syiah Kuala, 2015 http://www.academia.edu/14925898/ANALISIS PENGARUH MOTIVASI KEPEMIMPINAN DAN_LINGKUNGAN_KERJA TERHADAP KINERJA PEGA WAI_SERTA_DAMPAKNYA_PADA_KINERJA_DINAS

3) Bryan Yohanes Tampi, the journal Acta diurnal Vol III. No. 4. 2014. The Influence of Leadership Style and Motivation on Employee Performance at PT BNI , TBK (Regional Sales Manado) http://ejournal.unsrat.ac.id/index.php/actadiurna/ article/download/6228/5753

4) Eoh, Jeny. 2001. The Influence of Corporate Culture, Management Style and Team Development on Employee Performance: A Case Study at PT.Gresi and PT. Semen Kupang. Dissertation in Administrative Sciences, University of Indonesia Postgraduate Program. Jakarta.

5) Frederick Binfor, etc. Research Article the Effect of Leadership Styles and Motivation on Employee Performance in Public Institutions: Evidence from Ghana.

http://www.journalcra.com/sites/default/files/Download\%203944.pdf accessed April 17, 2016 at 10.00

6) Messa Media Gusti. 2012. The Effect of Discipline, Work Motivation, and Teachers' Perceptions of Principal Leadership on Teacher Performance at SMKN 1 Purworejo Post Certification.

https://core.ac.uk/download/files/335/11063990.pdf accessed March 31, 2016.

7) Gana, Frans. 2011. Knowledge Creation, Innovation and Business Competitiveness: A Flower Rampai; University of Indonesia. Jakarta. 
The Influence of Leadership Style and Motivation on Employee Performance in the Department Of Transportation, Tourism, Communication and Informatics in Ngada District

8) Gultum, Dedek Kurniawan. 2014. The Influence of Company Organizational Culture and Motivation on Employee Performance at PT. Perusahaan Gas Negara (Persero) Tbk Medan. Journal of Management and Business. Volume 14, Number 02, October. http://jurnal.umsu.ac.id.

9) Handoko, Hani T, Dr.MBA and Reksohadiprodjo Sukanto, Dr. M.Com. 1996. Company Organization. Second Edition Yogyakarta: BPFE Hutapea, Parulian, MBA and Dr. Nurianna Thoha, MBA. 2008. Competency Plus Theory, Design, Cases, and Applications for HR and Dynamic Organizations. Printing PT. Gramedia. Jakarta.

10) K oesmono, H. Friends. 2005. The Influence of Organizational Culture on Motivation and Job Satisfaction and Employee Performance in the Medium Scale Wood Processing Industry in East Java. Journal of Management and Entrepreneurship. Volume 7, Number 2, September. Pages 171-188. http://puslit.petra.ac.id.

11) Manganhardjana, A. M, SJ. 2006. Leadership. Publisher Kanisius. Yogyakarta.

12) Messa Media Gusti. 2012. The Effect of Discipline, Work Motivation, and Teachers' Perceptions of Principal Leadership on Teacher Performance at SMKN 1 Purworejo Post Certification.

https://core.ac.uk/download/files/335/11063990.pdf accessed March 31, 2016.

13) Miftah Thoha, 2012, Leadership in Management

14) Muhclas, Makmuri. 2012. Organizational Behavior. Gadjah Mada University Press. Yogyakarta.

15) Nazir. Moh. 2003. Research Methods. PT. Ghalia Indonesia. Jakarta.

16) Pasolong, Harbani. 2007. Public Administration Theory. Alfabeta. Bandung

17) Pasolong, Harbani. 2008. Bureaucratic Leadership. Alfabeta. Bandung

18) Raharjo, Susilo Toto and Durrotun Nafisah. 2006. Analysis of the Effect of Leadership Style on Job Satisfaction, Organizational Commitment and Employee Performance (Empirical Study at the Department of Religion, Kendal Regency and the Department of Religion, Semarang City). Journal of Management and Organizational Studies. Volume 3, Number 2, July. Page 69. http://ejournal.undip.ac.id/index.php/smo.

19) Ratmawati, DWI, Nurri Hercahmawati. 2014. Organizational Behavior. Open University Publisher. Banten.

20) Robbins, SP and Judge, Timothy A. 2008. Organizational Behavior. Book 1. Translation of Diana Angelica, RIA Cahyani and Abdul Rosyid. Four Salemba. Jakarta.

21) Simamora, Henry. 2006. Human Resource Management, Issue 2. STIE YKPN. Yogyakarta.

22) Sudarmadi. 2007. Analysis of the Influence of Organizational Culture and Leadership Style on Satisfaction and Performance of Administrative Employees at the University of Semarang. Semarang.

23) Sutrisno, Edy. 2011. Organizational Culture. Kencana Prenada Media. Jakarta.

24) Tobari, Dr. H., SEMSi. 2014. Building Organizational Culture in Government Agencies. Deepublish publisher. Yogyakarta.

25) Ukaejiofo Rex Uzonna, Impact of motivation on employees' performance: A case study of CreditWest Bank Cyprus. Agricultural University, Beijing http://www.academicjournals.org/journal/JEIF/article-full-text-pdf/A85765D28566 accessed April 21, 2016

26) Wahyuni, Sri, H. Adam Idris and Muhamad Noor. 2013. Factors Influencing Employee Performance at the Department of Agriculture and Livestock Services of East Kutai Regency. Ejournal Administrative Reform. 1 (2): 444-457. http://ar.mianfisip-unmul.ac.id.

27) Wibowo. 2011. Performance Management. Rajagrafindo Persada. Jakarta.

28) Quoted from www.jurnal.sdm.blogspot.com . Organizational Culture Theory Quoted from www.slideshare.net/IceuAdin ata/budaya-organization. Harding Diana. Organizational culture. 